\title{
Evaluation of the Mechanical Behavior of Local Brick Masonry in Pakistan
}

\author{
Tajik Mustafa Shah \\ Department of Civil Engineering, \\ Mehran University of Engineering \\ and Technology, Shaheed Zulfiqar \\ Ali Bhutto Campus, \\ Khairpur Mirs', Sindh, Pakistan \\ tajikmustafashah@live.com
}

\author{
Aneel Kumar \\ Department of Civil Engineering, \\ Mehran University of Engineering \\ and Technology, \\ Jamshoro, Sindh, Pakistan \\ aneel.kumar@faculty.muet.edu.pk
}

\author{
Syed Naveed Raza Shah \\ Department of Civil Engineering, \\ Mehran University of Engineering \\ and Technology, Shaheed Zulfiqar \\ Ali Bhutto Campus, \\ Khairpur Mirs', Sindh Pakistan \\ naveedshah@muetkhp.edu.pk
}

\author{
Ashfaque Ahmed Jhatial \\ Department of Civil Engineering, Mehran University of \\ Engineering and Technology, Shaheed Zulfiqar Ali Bhutto \\ Campus, Khairpur Mirs', Pakistan \\ ashfaqueahmed@muetkhp.edu.pk
}

\author{
Mudasar Hussain Janwery \\ Department of Civil Engineering, Mehran University of \\ Engineering and Technology, Shaheed Zulfiqar Ali Bhutto \\ Campus, Khairpur Mirs', Pakistan \\ mudasar.hussain999@gmail.com
}

\begin{abstract}
Masonry is the oldest form of construction in the world [1]. Research shows that it is the most widely used construction material in Pakistan and it has remained as such for more than the past hundred years. The majority of buildings in Pakistan are load-bearing burnt-brick masonry structures. Unfortunately, the brick masonry structures in Pakistan are not designed with respect to any regulatory code, because none exist. Consequently, these structures are not constructed according to a safe design and thus become hazardous and often face considerable damage and sometimes prove to be fatal. This study aims to study the behavior of local brick masonry under normal, shear and thermally challenging conditions and to model its behavior by relating the crushing strength (f'm) to the height-to-thickness ratio and temperature.
\end{abstract}

Keywords- brick masonry; elevated temperature; stress-strain diagram

\section{INTRODUCTION}

Brick masonry as a structural material is being used widely in the developing nations, while in the developed nations its use is complementary. A research has been conducted in order to obtain a view of the problems pertaining to this material. Failure of brick masonry structures or their roofs is a commodity. In Pakistan, all the research conducted to date is not based on the engineering and structural properties of this material, only the qualitative analysis of materials has been conducted. There is thus a need of experimental evaluation of the properties of brick masonry as a material. One of the first studies on the generalized characteristics of the brick masonry in Canada was carried out in [2]. This study evaluated the properties and the approximate behavior of brick masonry under different conditions. Author in [3] tried to evaluate the material properties of brick masonry. One of the first studies on the brick masonry of Pakistan was carried out in [4]. The author travelled across Pakistan and concluded that the majority of buildings in Pakistan were load-bearing structures. This study led to the generation of the $173^{\text {rd }}$ report on World Housing for Pakistan [5]. Following this, the very first engineering study on the local brick masonry in Sindh, Pakistan was conducted in [6]. Authors in [7-11] tried to model the behavior of brick masonry on various finite element packages. This led to the orientation of a whole new era on the engineering study of brick masonry. Recently, author in [12] studied a new way of brick masonry construction in Azad Kashmir. The behavior of local brick masonry in Pakistan is unknown because the material and its engineering properties are not known completely, furthermore, there are no codes in Pakistan governing the design and construction of brick masonry [5]. The most relevant code in terms of material, the IS 1905-87 [13] is limited to the uniaxial behavior of brick masonry. The materials and brick unit dimensions used in Pakistan are of different proportions as compared to the neighbouring states [6], so the properties will be utterly distinct.

This study aims to append the available engineering data for brick masonry in Pakistan so that an easy design method can be made and to lay a foundation for the numerical simulation of brick masonry for easier virtual experimentation and for the creation of regulatory codes. The objective of this work is to study the behavior of local brick masonry under normal, shear and thermally challenging conditions, to model its behavior by relating the crushing strength ( $\left.\mathrm{f}^{\prime} \mathrm{m}\right)$ to the height-to-thickness ratio $(\mathrm{h} / \mathrm{t})$ of brick masonry and temperature and to obtain the engineering properties of local brick masonry to make a base for numerical simulations. 


\section{MATERIALS AND METHODOLOGY}

\section{A. Materials}

The bricks were collected from a local supplier, in Khairpur Mirs'. The bricks were carefully examined to be of the same dimensions and consistency. The brick properties are shown in Table I. The mortar was made from sieved Sui sand and ordinary Portland cement manufactured by the Lucky Cement Ltd. The masonry units were built using a mason's trowel and finishing trowel by a local mason.

TABLE I. MECHANICAL PROPERTIES OF BRICKS [6]

\begin{tabular}{|c|c|}
\hline Property & Value \\
\hline Modulus of elasticity & $20.23 \mathrm{kN} / \mathrm{mm}^{2}$ \\
\hline Poisson's ratio & 0.21 \\
\hline Specific weight & $13.165 \mathrm{kN} / \mathrm{m}^{3}$ \\
\hline Specific gravity & 2.549 \\
\hline
\end{tabular}

\section{B. Experimental Procedure}

Compressive testing of bricks was done according to [14]. The mortar was tested as per [15]. The brick masonry under direct axial compression was tested according to $[14,16]$, according to [17] under shear compression, and at elevated temperature using the unstressed residual strength method employed in [18]. Three specimens were tested for each case, i.e. for one single brick, two-brick prisms, three-brick prisms, four-brick prisms and five-brick prisms. Three specimens of five-brick prisms were tested for each temperature of $50^{\circ} \mathrm{C}$, $100^{\circ} \mathrm{C}, 150^{\circ} \mathrm{C}, 200^{\circ} \mathrm{C}$ and at $250^{\circ} \mathrm{C}$. Three three-brick specimens were used for evaluation of shear behavior of brick masonry.

\section{RESULTS AND DISCUSSION}

The specimens were tested in a universal testing machine (UTM) under direct compression. The average stress-strain behavior of brick masonry obtained is shown in Figure 1. Table II shows the variation of strength with increase in height to thickness ratio of brick masonry.

Figure 2 shows the increase in slenderness of brick masonry with respect to the number of bricks in prism. Table III shows the variation of strength with respect to increase in temperature. Figure 3 shows the variation of strength with respect to increasing temperature. The average shear behavior of brick masonry is shown in Figure 4. Table IV shows the data obtained from the shear testing of samples.

\section{STRESS-STRAIN BEHAVIOUR OF LOCAL} BRICK MASONRY

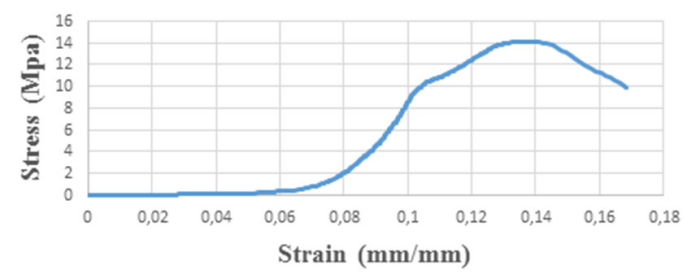

Fig. 1. Stress-strain behavior of local brick masonry
TABLE II. DATA OBTAINED FROM EXPERIMENTATION AT AMBIENT TEMPERATURES

\begin{tabular}{|c|c|c|c|c|c|c|}
\hline 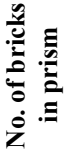 & 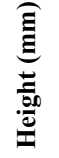 & 珶 & 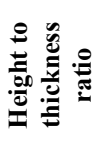 & 预 & نั & 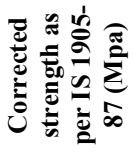 \\
\hline 1 & 90 & 97.5 & 0.923 & 13 & 0.46 & 5.98 \\
\hline 2 & 160 & 97.5 & 1.641 & 5 & 0.673 & 3.365 \\
\hline 3 & 235 & 97.5 & 2.41 & 4.1 & 0.786 & 3.226 \\
\hline 4 & 330 & 97.5 & 3.384 & 3.8 & 0.9 & 3.42 \\
\hline 5 & 380 & 97.5 & 3.897 & 3.6 & 0.942 & 3.391 \\
\hline
\end{tabular}

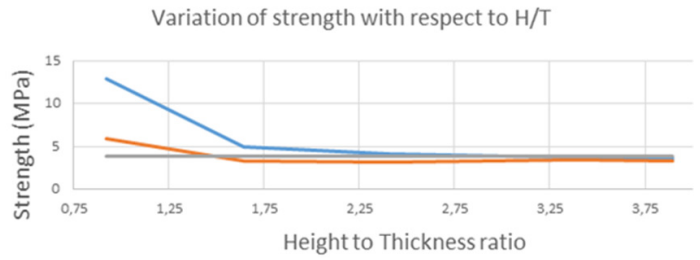

Fig. 2. Variation of strength with respect to change in $\mathrm{h} / \mathrm{t}$ ratio.

TABLE III. DATA OBTAINED FROM EXPERIMENTATION AT ELEVATED TEMPERATURES

\begin{tabular}{|c|c|c|c|c|c|c|c|}
\hline 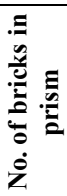 & 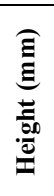 & 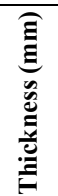 & 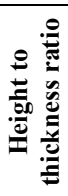 & 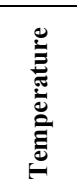 & 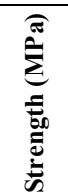 & ذّ & 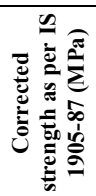 \\
\hline 5 & 380 & 97.5 & 3.897 & $50^{\circ} \mathrm{C}$ & 5.435 & 0.942 & 5.11977 \\
\hline 5 & 380 & 97.5 & 3.897 & $100^{\circ} \mathrm{C}$ & 5.4 & 0.942 & 5.0868 \\
\hline 5 & 380 & 97.5 & 3.897 & $150^{\circ} \mathrm{C}$ & 5.107 & 0.942 & 4.81079 \\
\hline 5 & 380 & 97.5 & 3.897 & $200^{\circ} \mathrm{C}$ & 4.512 & 0.942 & 4.2503 \\
\hline 5 & 380 & 97.5 & 3.897 & $250^{\circ} \mathrm{C}$ & 4.794 & 0.942 & 4.51595 \\
\hline
\end{tabular}

Variation of strength with temperature

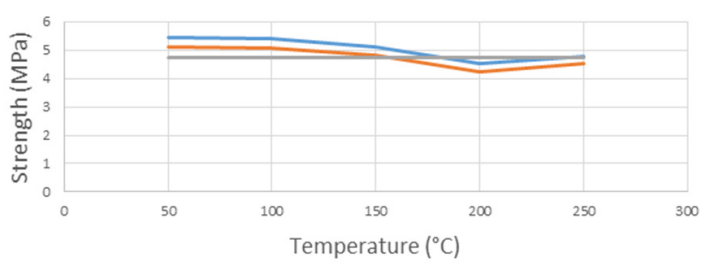

Fig. 3. Variation of strength of brick masonry with increasing temperature

SHEAR STRESS - SHEAR STRAIN BEHAVIOUR OF LOCAL BRICK MASONRY

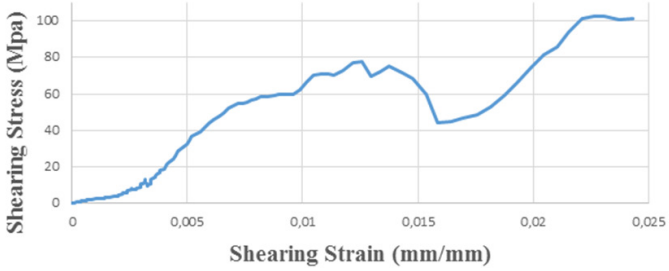

Fig. 4. The shear behaviour of brick masonry 
TABLE IV. DATA OBTAINED FROM SHEAR TEST

\begin{tabular}{|c|c|c|c|}
\hline $\begin{array}{c}\text { No. of bricks } \\
\text { in prism }\end{array}$ & $\begin{array}{c}\text { Overall height } \\
(\mathbf{m m})\end{array}$ & $\begin{array}{c}\text { Overall thickness } \\
(\mathbf{m m})\end{array}$ & $\begin{array}{c}\text { Shear strength } \\
\text { (MPa) }\end{array}$ \\
\hline 3 & 257 & 178 & 0.523 \\
\hline
\end{tabular}

\section{CONCLUSIONS}

- The average compressive strength of a single local brick is around $13 \mathrm{MPa}$.

- The average compressive strength of local brick masonry is around 3.764MPa.

- The stress-strain behavior of brick masonry follows a concave down curve.

- The strength of brick masonry decreases slightly with increasing slenderness.

- There is no significant effect of elevated temperature on the strength or behaviour of brick masonry, but the strength decreases slightly with increasing temperature.

- The average shear strength of local brick masonry is around $0.523 \mathrm{MPa}$

\section{REFERENCES}

[1] A. Khan, C. Lemmen, "Bricks and urbanism in the Indus valley, rise and decline", available at: https://arxiv.org/pdf/1303.1426.pdf, 2013

[2] T. Kaaki, Behaviour and Strength of Masonry Prisms Loaded in Compression, Dalhousie University, 2013

[3] D. Tensing, C. C. Freeda, S. R. Mercy, "Experimental study on axial compressive strength and elastic modulus of the clay and fly ash brick masonry", Journal of Civil Engineering and Construction Technology, Vol. 4, No. 4, pp. 134-141, 2013

[4] S. H. Lodi, "Brick masonry in Pakistan", International Conference on Sustainable Development in Civil Engineering, Jamshoro, Pakistan, November 21-25, 2017.

[5] S. H. Lodi, A. J. Sangi, A. Abdullah, Housing Report: Brick Masonry Construction in Pakistan, World Housing Encyclopedia, 2013

[6] S. Khoso, F. H. Wagan, J. S. Khan, N. u. K. Bhatti, A. A. Ansari, "Qualitative analysis of baked clay bricks available in Larkana region, Pakistan”, Architecture-Civil Engineering-Environment, Vol. 7, No. 2, pp. 41-50, 2014

[7] M. A. Rahemia, A. A. Tasnimib, A. Sarvghad-Moghadam, "Micromodeling of masonry infilled rc moment resisting frames to investigate arrangement of compressive diagonal struts", IJE Transaxtions C: Aspects, Vol. 27, No. 6, pp. 865-880, 2014

[8] S. Ravi, S. Viswanathan, T. Nagarajan, V. Srinivas, P. Narayanan, "Experimental and Numerical Investigations on Material Behaviour of Brick Masonry", 2nd International Conference on Research in Science, Engineering and Technology, Dubai, UAE, March 21-22, 2014

[9] S. R. Sarhat, E. G. Sherwood, "The prediction of compressive strength of ungrouted hollow concrete block masonry", Construction and Building Materials, Vol. 58, pp. 111-121, 2014

[10] S. Viswanathan, S. Ravi, T. Nagarajan, V. Srinivas, P. Narayanan, "Numerical Simulation of Compression and Shear Behaviour of Unreinforced Brick Masonry", International Conference on Biological, Civil and Environmental Engineering, Dubai, UAE, March 17-18, 2014

[11] H. S. Vindhyashree, A. Rahamath, W. P. Kumar, M. T. Kumar, "Numerical simulation of masonry prism test using ANSYS and ABAQUS", International Journal of Engineering Research and Technology, Vol. 4, No. 7, pp. 1019-1027, 2015

[12] R. Langenbach, "Recovering the Lost Moment: How Timber-Laced Masonry May Hold the Secret to Stopping Pancake Collapse of Concrete Moment Frames", First South Asia Conference on Earthquake Engineering, Karachi, Pakistan, February 21-22, 2019
[13] Bureu of Indian Standards, IS 1905 (1987): Code of Practice for Structural use of Unreinforced Masonry, Bureu of Indian Standards, 2010

[14] Bureu of Indian Standards, IS 3495-1 (1992): Methods of Tests of Burnt Clay Buildind Bricks, Bureu of Idian Standards, 1992

[15] Bureu of Indian Standards, IS 4031-6 (1988): Methods of Physical Tests for Hydraulic Cement, 2006

[16] British Standards Institution, BS EN 1052-1:1999, Methods of test for masonry. Determination of compressive strength, BSI, 1999

[17] British Standards Institution, EN 1052-3: 2002, Methods of test for masonry. Determination of initial shear strength, 2002

[18] L. T. Phan, N. J. Carino, "Code provisions for high strength concrete strength-temperature relationship at elevated temperatures", Materials and Structures, Vol. 36, No. 2, pp. 91-98, 2003 